This work is licensed under Creative Commons Attribution 4.0 International (CC BY 4.0). [http://creativecommons.org/licenses/by/4.0/]

\title{
Główne założenia Centralnej Komisji Kwalifikacyjnej w latach 1951-1953
}

Tomasz Solarski | Uniwersytet Gdański, Wydział Nauk Społecznych https://orcid.org/0000-0002-9452-5427

\section{Streszczenie}

Słowa kluczowe:

komisja, nauka, Polska, powojenny, struktury

Centralna Komisja Kwalifikacyjna pełniła istotną rolę w powojennej Polsce. Do jej głównych zadań należała nie tylko ocena dokonań naukowych kandydatów, ale również pozanaukowych czynników, określanych jako „moralność". Przyjęte przez prawodawcę akty prawne szczegółowo regulowały pracę Komisji oraz kryteria dla samodzielnych pracowników nauki.

The principles of Polish Central Classification Commission in the years 1951-1953

\section{Summary}

Polish Central Classification Commission played major role in postwar Poland. The Commission was eligible not only to evaluate candidate's science achievements but also another, non-scientific criteria called "morality". The law established by a lawmaker regulated Commission's tasks in detail, same as criteria for independent researchers. 


\section{Wstęp}

Niniejszy artykuł stanowi wstęp do badań nad problematyką wpływu Centralnej Komisji Kwalifikacyjnej dla Pracowników Nauki (CKK) na pedagogikę jako dyscyplinę nauki. Jego celem jest wskazanie najistotniejszych założeń leżących u podstaw powstania i funkcjonowania tej instytucji w kontekście powojennych wyzwań oraz przemian politycznych w Polsce. Kluczowe w tym kontekście jest omówienie najważniejszych regulacji dotyczących jej kompetencji, składu i trybu prac w oparciu o źródła prawa. Istotne jest również przedstawienie kryteriów przyznawania kandydatom tytułów przez CKK.

\section{Władza wobec środowiska naukowego w powojennej Polsce}

Po II wojnie światowej Polska znalazła się w strefie wpływów Związku Radzieckiego. Uznaje się, że w wyniku wprowadzonych przez ustawodawcę rozwiązań Polska miała charakter republiki satelickiej, a panujący ustrój był tzw. demokracją ludową, a więc taką, w której faktyczna władza sprawowana była przez jedną z partii. O ile ustawa konstytucyjna z dnia 19 lutego 1947 roku skupiła się wyłącznie na kwestiach ustrojowych, o tyle Konstytucja Rzeczypospolitej Polskiej z dnia 22 lipca 1952 roku regulowała również kwestie nauki. Konstytucja stanowiła, że Polska Rzeczpospolita Ludowa szczególną opieką otacza inteligencję twórczą i przyznawała obywatelom prawo do nauki (Konstytucja 1952). Artykuł 62 stanowił ponadto, że państwo „dba o wszechstronny rozwój nauki, opartej na dorobku przodującej myśli ludzkiej i postępowej myśli polskiej nauki w służbie narodu". Podkreśla się jednak, że choć Konstytucja PRL przyznawała szereg gwarancji, w tym również tych o charakterze politycznym, to w rzeczywistości prawa i wolności jednostek nie istniały i dopiero na przełomie lat 1956 i 1957 roku zarysowały się w systemie pewne elementy praworządności (Garlicki 2011: 14).

Efektem zmian politycznych w Polsce były reformy związane z kształceniem kadr naukowych. Środowisko naukowe niechętne było bowiem przemianie władzy, co z kolei nie pozostawało bez reakcji rządu. Minister oświaty Stanisław Skrzeszewski już w 1947 roku podczas przemówienia w ramach Zjazdu Akademickiego Związku Walki Młodych „Życie” zarzucał środowisku akademickiemu opór wobec przemian politycznych i ekonomicznych w Polsce, utrudnianie dostarczania kadr do przemysłu i brak zainteresowania doświadczeniami nauki w ZSRR (Grzybowski 2000: 67). Jeszcze wcześniej, bo w 1945 roku, pierwszy sekretarz partii Władysław Gomułka wskazywał, że „my dopiero musimy wychować naszych profesorów i wychowamy na pewno, ale dopiero po latach, po okresie potrzebnym na wychowanie profesora". Władza miała ambicje wpływania na wszystkie dziedziny życia społeczno-gospodarczego w Polsce, w tym również na naukę, czego wyrazem stało się funkcjonowanie przy komitetach wojewódzkich PZPR wydziałów nauki, oświaty i kultury, których działania związane były z wpływaniem na środowiska oświatowe i naukowe (Bądkowski 2012: 86-87). 
Wśród postulatów wysuwanych w 1949 roku na Plenum KC PZPR znalazły się m.in. reorientacja metodologiczna nauki polskiej i upowszechnienie doświadczeń nauki radzieckiej oraz zaostrzenie kryteriów politycznych przy ocenie pracowników naukowych. Problemem były również braki kadrowe. W czasie wojny wśród tylko profesorów historii zginęło aż 28,5\%, a w 1945 roku było ich około 50. Podczas V Plenum KC PZPR w 1950 roku członek Komitetu Centralnego Zenon Nowak podkreślał, że „liczba profesorów wynosi obecnie 2200 wobec około 1800 przed wojną, co stanowi wzrost o około 22\% w tym czasie gdy liczba studentów wzrosła z 48 tysięcy w 1939 roku do 116 tysięcy, tzn. o przeszło 140\%" (Kolbuszewska 2016: 156-158).

W 1950 roku podjęto prace nad wprowadzeniem, wzorowanego na rozwiązaniach radzieckich, systemu aspirantury zamiast dotychczasowej asystentury. Dążeniu do zwiększania tempa kształcenia kadry towarzyszyło dążenie do tego, by kandydaci wykazywali odpowiednią postawę społeczno-polityczną i moralną, co wiązało się z nadawaniem prawa głosu w kwestiach zatrudnienia partiom politycznym i organizacjom młodzieżowym. Kwalifikowanie pracowników nauki powierzono także Centralnej Komisji Kwalifikacyjnej (Chodakowska 1981: 169-172).

\section{Powstanie i funkcjonowanie Centralnej Komisji Kwalifikacyjnej}

Centralna Komisja Kwalifikacyjna utworzona została na mocy ustawy z dnia 15 grudnia 1951 roku o szkolnictwie wyższym i o pracownikach nauki, która weszła w życie 7 lutego 1952 roku. Zgodnie z art. 56 do kompetencji Komisji należało przyznawanie tytułów przewidzianych dla samodzielnych pracowników nauki, czyli tytułu profesora zwyczajnego, profesora nadzwyczajnego i docenta. Należy przy tym wskazać, że zgodnie z ustawą drugą odrębną kategorię stanowili pomocniczy pracownicy nauki, a więc adiunkci, starsi asystenci i asystenci. Komisja, dokonując oceny, zobowiązana była brać pod uwagę nie tylko kwalifikacje naukowe i wyniki działalności naukowej pracownika, ale również kwalifikacje moralne. W skład komisji wchodzili: przewodniczący, powołany przez Prezydenta Rzeczypospolitej na wniosek Prezesa Rady Ministrów, oraz członkowie, powołani przez Prezesa Rady Ministrów spośród samodzielnych pracowników nauki. Organizację oraz zakres i tryb działania CKK ustalał regulamin, nadawany przez Radę Ministrów na podstawie art. 50 ust. 2 ustawy (ustawa 1951). Zgodnie z regulaminem Centralna Komisja Kwalifikacyjna dzieliła się na sekcje:

- nauk społecznych,

- nauk biologicznych,

- nauk matematyczno-fizycznych, chemicznych i geologo-geograficznych,

- nauk technicznych.

Wybór składu osobowego tych sekcji dokonywany był przez CKK na zebraniu ogólnym. Prezydium Centralnej Komisji Kwalifikacyjnej, w skład którego wchodził przewodniczący Centralnej Komisji Kwalifikacyjnej, przewodniczący sekcji oraz co najmniej trzech członków Komisji wybranych na zebraniu ogólnym, uprawnione było, 
za zgodą Prezydium Rządu, tworzyć również inne sekcje niż wskazane w ustawie. Co istotne, członkami CKK mogli być wyłącznie profesorowie zwyczajni i nadzwyczajni, a więc nie docenci (obwieszczenie M.P.1952.A-42.601).

Centralna Komisja Kwalifikacyjna wszczynała postępowanie kwalifikacyjne w sprawie przyznania tytułu naukowego przewidzianego dla samodzielnych pracowników nauki na wniosek szkoły wyższej, instytutu naukowego lub innej placówki naukowej, zgłoszony przez właściwego ministra albo przez Prezydium Polskiej Akademii Nauk. Wstępnej oceny kandydata dokonywała odpowiednia dla danej nauki sekcja, a następnie przedstawiała ją Prezydium Centralnej Komisji Kwalifikacyjnej, które jednak, podobnie jak ogólne zebranie Centralnej Komisji Kwalifikacyjnej, nie było w żaden sposób tą oceną związane.

Działalność CKK nie obejmowała wyłącznie przyznawania pracownikom nauki tytułów naukowych, Komisja miała także kompetencje w zakresie:

- ustalania wytycznych dla komisji kwalifikacyjnych dla pomocniczych pracowników nauki oraz sprawowania kontroli działalności tych komisji,

- zatwierdzania stopni naukowych nadawanych przez szkoły wyższe, instytuty naukowe lub inne placówki naukowe,

- rozpatrywania wniosków o pozbawienie tytułu naukowego pracownika nauki ukaranego dyscyplinarnie wydaleniem z pracy,

- rozpatrywania wniosków o przywrócenie praw utraconych na skutek pozbawienia pracownika nauki tytułu naukowego.

W początkowym okresie Komisja nie działała w ogóle, co oznaczało zablokowanie awansów naukowych, a jej pierwsze posiedzenie odbyło się dopiero 29 kwietnia 1953 roku. Przewodniczącym powołany został Minister Szkolnictwa Wyższego Adam Rapacki, a sekretarzem profesor chemii i podsekretarz stanu Osman Achmatowicz. Komisja liczyła 102 członków i około 500 rzeczoznawców, których zadaniem było wydawanie opinii, na podstawie których dokonywano oceny prac naukowych (Hubner 1992: 657-658).

Uchwały Centralnej Komisji Kwalifikacyjnej oraz jej Prezydium zapadały zwykłą większością głosów, a w razie równości głosów decydujący charakter miał głos przewodniczącego. Uchwała nr 1, która weszła w życie 15 lipca 1953 roku, podjęła problematykę kryteriów przyznawania stopnia kandydata nauk, stanowiąc, że muszą one odpowiadać rosnącym wymaganiom stawianym przez potrzeby gospodarki i kultury narodowej w zakresie wykonywanych przez samodzielnych pracowników nauki badań naukowych i jakości kształconych przez nich kadr socjalistycznej inteligencji. Wśród wyszczególnionych kryteriów zaznaczono konieczność wykazania się przez kandydata znajomością zasad materializmu dialektycznego i historycznego. Dodatkowym, obligatoryjnym kryterium, które podlegało ocenie CKK, były ponadto kwalifikacje moralne i obywatelskie kandydata (obwieszczenie M.P.1953.A-66.806). 


\section{Kryteria przyznawania tytułów przez Centralną Komisję Kwalifikacyjną}

Podstawowym kryterium umożliwiającym ubieganie się o przyznanie tytułu docenta było posiadanie stopnia kandydata nauk. Kandydat powinien był ponadto swoją dotychczasową pracą naukową i dydaktyczną dawać rękojmię, że będzie wykonywać obowiązki pracownika nauki zgodnie z potrzebami gospodarki i kultury narodowej, a także wykazywać się umiejętnością kierowania pracą naukową oraz co najmniej pięcioletnią pracą na stanowiskach pomocniczego pracownika nauki i posiadać tytuł adiunkta. Co istotne, do tego okresu wliczał się okres aspirantury. Ponadto CKK uprawnione było do przyznania tytułu osobie, która posiadała krótszy okres pracy, ale ukończyła studia aspiranckie i wyróżniała się wynikami w pracy naukowej i w praktyce pedagogicznej, bądź uzyskała stopień kandydata nauk bez aspirantury, ale miała poważne doświadczenie w pracy zawodowej związanej z dyscypliną, która była przedmiotem pracy kandydackiej, oraz posiadała umiejętność prowadzenia pracy dydaktycznej (obwieszczenie M.P.1953.A-66.808). Tryb nadawania tytułu docenta szczegółowo regulowały wytyczne Prezydium Centralnej Komisji Kwalifikacyjnej dla Pracowników Nauki z dnia 2 czerwca 1953 roku w sprawie składania i rozpatrywania wniosków o nadanie tytułu naukowego docenta (obwieszczenie M.P.1953.A-66.809).

Komisja określiła również zasady przyznawania w przypadkach wyjątkowych tytułu naukowego docenta inżynierom-magistrom pełniącym obowiązki samodzielnych pracowników nauki w szkołach wyższych i instytutach naukowo-badawczych (obwieszczenie M.P.1953.A-99.1368). Wystąpienie o przyznanie tytułu było dopuszczalne w przypadku osób, które:

1) pełnią obowiązki samodzielnego pracownika nauki w szkole wyższej lub instytucie naukowo-badawczym co najmniej od 5 lat lub mogą się wykazać co najmniej dziesięcioletnią pracą na stanowiskach pracy wymagających samodzielnego stosowania metod naukowych, a w tym najmniej trzyletnią pracą w charakterze pełniącego obowiązki samodzielnego pracownika nauki w szkole wyższej lub instytucie naukowo-badawczym;

2) posiadają dorobek naukowy, a w nim pracę naukową odpowiadającą wymaganiom określonym dla prac kandydackich ogólnymi przepisami i uchwałą nr 1 CKK, wykonaną w okresie nie dłuższym niż 3 lata przed datą wystąpienia z wnioskiem o przyznanie tytułu naukowego docenta;

3) posiadają umiejętność kierowania pracą naukowo-badawczą i przejawiają twórczą inicjatywę w systematycznym prowadzeniu tej pracy w służbie rozwoju gospodarki i kultury narodowej;

4) wypełniają nienagannie inne obowiązki pracownika nauki:

a) współudział w tworzeniu planów badań naukowych i prac dydaktycznych,

b) rozwijanie pracy zespołowej w nauce,

c) udział w pracy nad kształceniem i wychowaniem kadr inteligencji ludowej zgodnie z programami i planami nauczania, 
d) udział w pracach organizacyjnych w zakresie nauczania i badań naukowych,

e) systematyczna praca nad upowszechnieniem nauki i szerzeniem naukowego poglądu na świat.

Regulacji doczekały się również zasady przyznawania tytułu naukowego profesora nadzwyczajnego i zwyczajnego. Zgodnie z uchwałą nr 4 CKK warunkiem przyznania tytułu naukowego profesora nadzwyczajnego było posiadanie stopnia naukowego kandydata nauk bądź doktora nauk oraz tytułu naukowego docenta. Posiadanie zaś stopnia naukowego doktora nauk i tytułu naukowego profesora nadzwyczajnego było warunkiem przyznania tytułu naukowego profesora zwyczajnego.

Zgodnie z ust. 2 uchwały kandydat na profesora nadzwyczajnego musiał w ciągu dotychczasowego paroletniego pełnienia nienagannie obowiązków samodzielnego pracownika nauki wykazywać się:

1) stale rozwijającą się działalnością naukowo-badawczą oraz stałym wzrostem poziomu dorobku naukowego wyrażającego się w pracach naukowych;

2) twórczą inicjatywą w organizowaniu i systematycznym prowadzeniu pracy naukowo-badawczej oraz troską o wychowywanie młodej kadry naukowej;

3) stałą i skuteczną troską o udoskonalanie metod i podnoszenie wyników nauczania - w przypadkach ubiegania się o tytuł profesora nadzwyczajnego osób pracujących w szkołach wyższych.

Wystąpienie o nadanie tytułu naukowego profesora zwyczajnego było natomiast dopuszczalne, gdy kandydat w ciągu kilkuletniej pracy na stanowisku profesora nadzwyczajnego, wypełniając nienagannie obowiązki pracownika nauki, wykazał się:

1) stale rosnącym dorobkiem naukowym, stanowiącym twórczy wkład do rozwoju danej dziedziny nauki;

2) poważnymi osiągnięciami w organizowaniu i kierowaniu pracą naukowo-badawczą w służbie gospodarki narodowej i kultury oraz poważnymi rezultatami w wychowywaniu kadry naukowej;

3) stałym wzrostem wyników w pracy nad kształceniem i wychowywaniem młodzieży - w przypadku ubiegania się o tytuł profesora zwyczajnego osób pracujących w szkołach wyższych (obwieszczenie M.P.1953.A-99.1369).

W odpowiedzi na nagromadzenie się znacznej ilości wniosków o wszczęcie przewodów kandydackich, co wynikało z wielomiesięcznego okresu przejściowego, w którym Komisja nie funkcjonowała, przyjęte zostały wytyczne w sprawie zasad kolejności przeprowadzania przewodów kandydackich, które wprost wskazywały radom wydziałowym w szkołach wyższych i radom naukowym w instytutach naukowych, w jakiej kolejności powinny przeprowadzać przewody kandydackie (obwieszczenie M.P.1953.A-66.807). Kolejność ta przedstawiała się następująco:

1) osoby, co do których na podstawie pisemnej opinii promotora oraz dwóch samodzielnych pracowników nauki z danej dyscypliny lub dyscyplin pokrewnych zostało stwierdzone, że ich praca naukowa odznacza się wysokim poziomem nauko- 
wym, stanowi twórczy wkład do nauki i posiada szczególne znaczenie dla rozwoju gospodarki i kultury narodowej;

2) samodzielni pracownicy nauki lub pełniący obowiązki samodzielnych pracowników nauki, aspiranci, pomocniczy pracownicy nauki;

3) inne osoby pełniące funkcje dydaktyczne i naukowe w szkołach wyższych i instytutach naukowych;

4) inżynierowie zatrudnieni w zakładach produkcyjnych, biurach konstrukcyjnych i projektowych, nauczyciele i lekarze;

5) pracownicy instytucji centralnych zatrudnieni w działach pracy wymagających samodzielnego stosowania metod naukowych w pracy zawodowej;

6) osoby posiadające poważne doświadczenie i osiągnięcia w pracy zawodowej związanej z dyscypliną, która jest przedmiotem pracy kandydackiej;

7) inne osoby.

W przypadku gdy równorzędnych kandydatów było kilku, o pierwszeństwie decydowało zapotrzebowanie kadrowe. Jeśli nie można było na jego podstawie dokonać rozstrzygnięcia, decydowała data złożenia pracy kandydackiej.

\section{Zakończenie}

Analizując podstawy powstania Centralnej Komisji Kwalifikacyjnej dla Pracowników Nauki, należy wymienić problemy kadrowe szkolnictwa wyższego powojennej Polski, a także stosunek środowiska akademickiego do przemian ustrojowych. Wśród kompetencji CKK najistotniejsze wydaje się przyznanie jej uprawnień do poddawania ocenie nie tylko kwalifikacji naukowych kandydatów, ale przede wszystkim kwalifikacji moralnych. Analiza źródeł prawa niewątpliwie nie jest w stanie udzielić odpowiedzi na wszystkie rodzące się pytania, jak choćby te dotyczące korelacji pomiędzy poglądami ideologicznymi, religijnymi bądź przynależnością organizacyjną autora a odrzuceniem jego kandydatury. Badania nad tą problematyką będą kontynuowane w oparciu o metodologię badań historycznych, w tym przede wszystkim analizę materiałów archiwalnych.

\section{Bibliografia}

Bądkowski A., 2012, Kierownicy Wydziału Nauki, Oświaty i Kultury KW PZPR w Poznaniu - przykłady karier partyjnych [w:] P. Gasztold-Senia, Ł. Kamiński (red.), Letnia Szkoła Historii Najnowszej 2011. Referaty, Warszawa.

Chodakowska J., 1981, Rozwój szkolnictwa wyższego w Polsce Ludowej w latach 1944-1951, Wrocław. Garlicki L., 2011, Polskie prawo konstytucyjne, Warszawa.

Grzybowski R., 2000, Wyższe szkoły pedagogiczne w Polsce w latach 1946-1956, Gdańsk. Hubner P., 1992, Polityka naukowa w Polsce w latach 1944-1953. Geneza systemu, Wrocław. 
Kolbuszewska J., 2016, Akademickie kariery kobiet w PRL-u. Historyczki-samodzielne pracownice nauki w nowopowstałych uniwersytetach, "Sensus Historiae”, nr 3.

Konstytucja Rzeczypospolitej Polskiej z dnia 22 lipca 1952 r. (Dz.U. z 1952 r. Nr 33, poz. 232).

Gasztold-Senia P., Kamiński Ł. (red.), 2012, Letnia Szkoła Historii Najnowszej 2011. Tom V. Referaty, Warszawa.

Obwieszczenie przewodniczącego Centralnej Komisji Kwalifikacyjnej dla Pracowników Nauki z dnia 27 czerwca 1953 r. dotyczące ogłoszenia uchwały nr 1 Centralnej Komisji Kwalifikacyjnej dla Pracowników Nauki z dnia 29 kwietnia 1953 r. w sprawie zasad postępowania przy nadawaniu stopnia kandydata nauk (M.P.1953.A-66.806).

Obwieszczenie przewodniczącego Centralnej Komisji Kwalifikacyjnej dla Pracowników Nauki z dnia 27 czerwca 1953 r. dotyczące ogłoszenia uchwały nr 2 Centralnej Komisji Kwalifikacyjnej dla Pracowników Nauki z dnia 29 kwietnia 1953 r. w sprawie zasad przyznawania tytułu naukowego docenta (M.P.1953.A-66.808).

Obwieszczenie przewodniczącego Centralnej Komisji Kwalifikacyjnej dla Pracowników Nauki z dnia 27 czerwca 1953 r. dotyczące ogłoszenia wytycznych Prezydium Centralnej Komisji Kwalifikacyjnej dla Pracowników Nauki z dnia 2 czerwca 1953 r. w sprawie składania i rozpatrywania wniosków o nadanie tytułu naukowego docenta (M.P.1953.A-66.809).

Obwieszczenie przewodniczącego Centralnej Komisji Kwalifikacyjnej dla Pracowników Nauki z dnia 6 października 1953 r. dotyczące ogłoszenia uchwały nr 3 Centralnej Komisji Kwalifikacyjnej dla Pracowników Nauki z dnia 3 października 1953 r. w sprawie zasad przyznawania w przypadkach wyjątkowych tytułu naukowego docenta inżynierom-magistrom pełniącym obowiązki samodzielnych pracowników nauki w szkołach wyższych i instytutach naukowo-badawczych (M.P.1953.A-99.1368).

Obwieszczenie przewodniczącego Centralnej Komisji Kwalifikacyjnej dla Pracowników Nauki z dnia 6 października 1953 r. dotyczące ogłoszenia uchwały nr 4 Centralnej Komisji Kwalifikacyjnej dla Pracowników Nauki z dnia 3 października 1953 r. w sprawie zasad przyznawania tytułu naukowego profesora nadzwyczajnego i zwyczajnego (M.P.1953.A-99.1369).

Obwieszczenie przewodniczącego Centralnej Komisji Kwalifikacyjnej dla Pracowników Nauki z dnia 27 czerwca 1953 r. dotyczące ogłoszenia wytycznych Prezydium Centralnej Komisji Kwalifikacyjnej dla Pracowników Nauki z dnia 2 czerwca 1953 r. w sprawie zasad kolejności przeprowadzania przewodów kandydackich (M.P.1953.A-66.807).

Uchwała nr 1116 Rady Ministrów z dnia 28 listopada 1952 r. w sprawie ustalenia wykazu szkół wyższych uprawnionych do nadawania stopnia kandydata nauk. (M.P.1953.A-1.12).

Uchwała nr 339 Rady Ministrów z dnia 26 kwietnia 1952 r. w sprawie regulaminu Centralnej Komisji Kwalifikacyjnej dla Pracowników Nauki (M.P.1952.A-42.601).

Ustawa z dnia 15 grudnia 1951 r. o szkolnictwie wyższym i o pracownikach nauki (Dz.U. z 1952 r. Nr 6, poz. 38).

\section{Biogram}

Tomasz Solarski - doktorant w Instytucie Pedagogiki na Wydziale Nauk Społecznych Uniwersytetu Gdańskiego. Absolwent politologii na Uniwersytecie Gdańskim oraz prawa w WSAiB w Gdyni. Obecne zainteresowania naukowe koncentrują się na zagadnieniach związanych z historią nauki oraz prawnymi i politycznymi instytucjami RP. 